\title{
East Antarctic ice-sheet dynamics between 5.2 and 0 Ma from a high-resolution terrigenous particle size record, ODP Site 1165, Prydz Bay-Cooperation Sea
}

\author{
S. Passchier
}

Department of Earth and Environmental Studies, Montclair State University, Upper Montclair, NJ 07043, USA (passchiers@ mail.montclair.edu)

Abstract This paper discusses a 5.2-0 Ma high-resolution terrigenous particle size record recovered from a sediment drift off East Antarctica. The particle size properties of Hole 1165B are interpreted in the context of previously acquired data on a continental shelf to slope transect drilled by ODP Leg 188 in Prydz Bay and the Cooperation Sea. The new data indicate that the Lambert ice stream stayed predominantly landward of the shelf break in the early Pliocene (5.2-3.5 Ma) with periods of ice sheet recession on land. The middle Pliocene (3.5-3.1 Ma) is characterized as major ice expansion during glacials with deposition of laminated clays from meltwater plumes on the continental rise, alternating with periods of ice recession. A change in sedimentary facies and a decrease in sedimentation rates occurred at $\sim 3.1 \mathrm{Ma}$ indicating a more retreated Lambert Glacier. Between 2.5 and $1 \mathrm{Ma}$ the ice stream was generally stable and had become cold-based with ice flow in a glacial trough extending to the shelf break. Three-four large pulses of coarse-grained glacigenic debris mark the record at $\sim 1 \mathrm{Ma}$. These are interpreted as extensive calving due to decoupling of the marine terminus from its bed in response to Northern Hemisphere deglaciations and associated sea level rises.

Citation: Passchier, S. (2007), East Antarctic ice-sheet dynamics between 5.2 and 0 Ma from a high-resolution terrigenous particle size record, ODP Site 1165, Prydz Bay-Cooperation Sea, in Antarctica: A Keystone in a Changing World - Online Proceedings of the $10^{\text {th }}$ ISAES, edited by A.K.

Cooper and C.R. Raymond et al., USGS Open-File Report 2007-1047, Short Research Paper 043, 4 p.; doi:103133/of2007-1047.srp043

\section{Introduction}

Recently, several authors have proposed an Antarctic component as an explanation for Pliocene-Pleistocene proxy records of ice volume and eustasy (Naish, 1997; Lambeck et al., 2002; Chappell, 2002; Raymo et al., 2006). Traditionally, the correlation of ice-rafted debris (IRD) and fluctuations in the $\delta{ }^{18} \mathrm{O}$ record in the Northern Hemisphere $(\mathrm{NH})$ were cited as evidence for a $\mathrm{NH}$ dominance of changes in global ice volume since $\sim 3 \mathrm{Ma}$. However, interpretations of IRD records are complex, because sea level as an external control can force marinegrounded ice sheets and glaciers to disintegrate through the process of decoupling. As a result, both the $\delta{ }^{18} \mathrm{O}$ and the IRD signal of a deep-sea core can be forced by an ice sheet situated at considerable distance. Studies of sedimentary records of high-latitude continental margins are, therefore, essential in reconstructions of the cryosphere and to ground truth interpretations of climate and sea level proxies.

One objective of Ocean Drilling Program (ODP) Leg 188 was to investigate the Neogene history of the East Antarctic ice sheet by drilling a continental shelf to rise transect off Prydz Bay, East Antarctica (Figure 1). The Prydz Bay area is the depocenter for sediment supplied by the Lambert Glacier, which drains about $12 \%$ of the total East Antarctic ice volume and is therefore very sensitive to changes in its mass balance. In order to reconstruct the record of Neogene expansions of the Lambert Glacier, three sites were drilled off Prydz Bay. Site 1166 was situated on the continental shelf, Site 1167 on the Prydz Channel trough-mouth fan, and Site 1165 penetrated a contourite sediment drift on the continental rise (Shipboard Scientific Party, 2001).

Sites 1167 and 1166 yielded a late Pliocene-present record of ice-stream behavior (Passchier et al., 2003). Iceproximal strata carry valuable direct evidence of glaciation, but their chronology is poor and the sequences are riddled by hiatuses. The off-shore strata at Site 1165 are more continuous, but the records are not as easy to interpret because of the effects of oceanographic processes and a decreased sediment supply during times of glacial recession when sediment is trapped inland. Here terrigenous particle size data of Site 1165 are interpreted in the context of previous studies on ice-proximal strata to reconstruct the glacial dynamics in a land to sea transect over the past 5.2 million years.

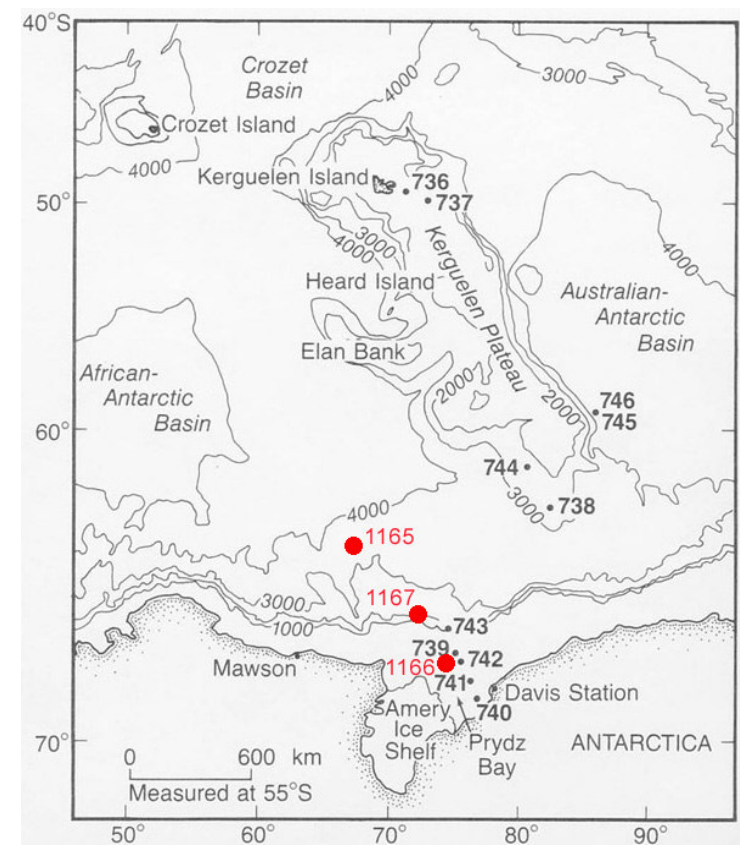

Figure 1. Location of drillsites in Prydz Bay and the Cooperation Sea. Leg 188 Sites in red. Adapted from: doi:10.2973/odp.proc.ir.119.102.1989 


\section{Materials and methods}

A total of 208 samples between 0 and $54.17 \mathrm{mbsf}$ were analyzed to provide a high-resolution terrigenous particle size record for Site 1165 (Figure 2). Sediments in this interval of core are characterized as three facies (Shipboard Scientific Party, 2001). Facies 1 consists of structureless yellowish gray to brown diatom clay with locally abundant foraminifera. This facies dominates the core interval between $\sim 1.5$ and $\sim 23$ mbsf. Facies 2 consists of interbedded 2-5 m thick units of greenish gray diatom-bearing clay, and dark grayish brown diatombearing clay. This facies assemblage is mainly found below $\sim 23$ mbsf. The dark grayish brown units are laminated between $\sim 25$ and $\sim 33$ mbsf. Facies 3 consists of diatom ooze and is only present in two short intervals in the upper $1.5 \mathrm{~m}$ of the core and at $\sim 14 \mathrm{mbsf}$.

The samples were pretreated with $30 \% \mathrm{H}_{2} \mathrm{O}_{2}, 10 \%$ $\mathrm{HCl}$, and $0.2 \mathrm{M} \mathrm{NaOH}$ solution, to remove biogenic components and to preserve only the terrigenous silicate fraction. Samples were dispersed by heating with sodium pyrophosphate and cooled. Grain-size distributions were measured on a Malvern Mastersizer 2000 laser particle sizer with a size range of $0.2-2000 \mu \mathrm{m}$.

Previously published data on the clay mineralogy of the same strata at Site 1165 (Junttila et al., 2005) and the sedimentology of Sites 1166 and 1167 (Passchier et al., 2003) are integrated in the sedimentological interpretation of the particle size results. The age model applied here is that of Warnke et al. (2004) adjusted towards the Gradstein et al. (2004) chronology.

Table 1. Average clay, silt, and sand $\%$ in the terrigenous fraction of each facies, Hole 1165B.

$\begin{array}{llll}\text { Facies } & \text { \% Clay } & \text { \% Silt } & \text { \% Sand } \\ 1 & 43 & 49 & 9 \\ \text { 2 - greenish gray } & 35 & 53 & 12 \\ \text { 2 - dark gray } & 33 & 55 & 12 \\ \text { 2 - laminated } & 50 & 47 & 3 \\ 3 & 49 & 43 & 8\end{array}$

\section{Results}

The structureless greenish gray and dark gray diatombearing clays of Facies 2 generally have a larger silt (4-63 $\mu \mathrm{m})$ and sand $(63-2000 \mu \mathrm{m})$ component than the yellowbrown diatom clay of Facies 1 (Table 1). The average particle size results do not show a significant difference between the structureless greenish gray and dark gray diatom-bearing clays of Facies 2. The terrigenous fraction of Facies 3, the diatom ooze and the laminated diatom clays of Facies 2 are clay-rich $(<4 \mu \mathrm{m})$.

The upper 54 mbsf of Site 1165 can be subdivided into 4 sections based on particle-size properties (Figure 2). From bottom to top: section I (54-35 mbsf) represents relatively silt-rich sediments. Despite the fact that the two different colored beds on average do not show a significant difference in grain-size distribution, 2-5 m scale fluctuations in grain-size are visible. Both normal grading and reverse grading is present. Some sand-rich spikes occur in the lower half of the interval and are associated with poor sorting of the fraction $<125 \mu \mathrm{m}$. A dramatic change in grain-size parameters is obvious at 35 mbsf between Section I and the overlying Section II (35-17 mbsf). Section II is characterized by higher clay percentages. Laminated interbeds (Facies 2) in this section are moderately sorted and some silt peaks with up to $87 \%$ silt occur. Towards the top of the interval the sand $\%$ increases and the sorting of the fraction $<125 \mu \mathrm{m}$ decreases. This trend abruptly terminates at 17 mbsf. Section III (17-9 mbsf) is characterized by relatively wellsorted silty clays with $<12 \%$ sand and an upward decreasing trend to $<5 \%$ sand in the upper half of the interval. Section IV (9-0.5 mbsf) shows an increase in sand $\%$ and coinciding peaks of poorly sorted fine fraction. The uppermost portion of Section IV at 0.5-0 mbsf is characterized by a sharp increase in clay $\%$.

\section{Sedimentological interpretation}

The large silt-sized terrigenous component and poor sorting of the sediments in Section I is indicative of a large supply of glacial rock flour produced by abrasion of crystalline basement. The sediments in Section I can therefore be attributed to a wet-based glacier. Cyclical gradational changes in color and particle size are typical of high-latitude deep-water contourites (Ehrmann and Grobe, 1991; Pudsey, 2000). The silt and sand-rich beds are associated with high smectite contents in the clay fraction (Junttila et al., 2005) indicating glacial recession, if the smectite formed under conditions of chemical weathering in the foreland of a glacier. In constrast, the clay rich beds contain mainly illite, which is supplied by physical erosion of crystalline basement, or by reworking of pre-existing marine sediments upon glacial expansion.

The particle size of Section II marks deposition of sediment from a glacier supplying mainly mud. In this interval, the dark gray diatom-bearing clays are locally laminated. The laminated beds are clay-rich and contain abundant illite (Junttila et al., 2005). No obvious graded beds are present, but sedimentation rates are high. Therefore, deposition from meltwater-generated sediment plumes from glacial ice situated at the shelf break is the most likely interpretation (Pudsey, 2000). The structureless interbeds between the laminated intervals have higher sand content and contain more smectite. These intervals represent phases of glacial recession when supply of glacigenic mud plumes is low and only icebergs reach the site. The laminated beds at Site 1165 can be interpreted as glacial sediments and the structureless smectite-rich interbeds as interglacial sediments (Pudsey, 2000).

Towards the top of Section II the relative abundance of IRD increases due to low background sedimentation rates. Smectite \% declines upsection (Junttila et al., 2005) indicating that chemical weathering decreased as well. The transition in sedimentological properties is also recognized as a facies change. 


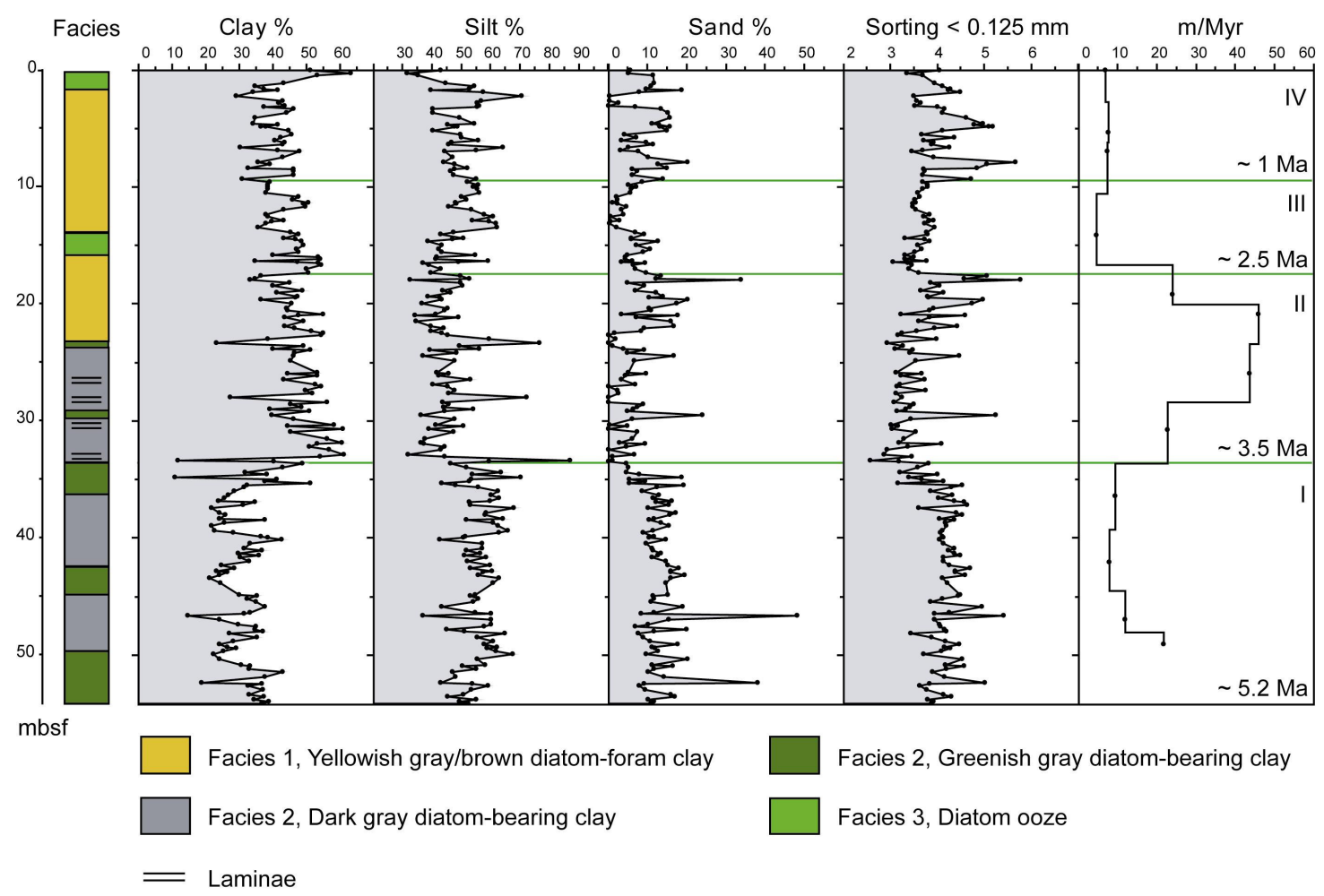

Figure 2. Terrigenous particle size data and sedimentation rates for ODP Hole 1165B.

Section III marks a period of relatively low supply of terrigenous sediment to the continental rise. The sand $\%$ is affected by winnowing of fines, as indicated by the sorted fine fraction in some intervals. The clay mineralogy shows a significant increase in kaolinite (Junttila et al., 2005). The low sedimentation rates, lack of significant IRD, and the clay mineralogy suggest that a large portion of the ice-sheet became frozen to its bed with glacial erosion of kaolinite-bearing sedimentary rocks.

Section IV shows a renewal of episodic supply of a relatively large component of poorly sorted glacigenic debris, as 3-4 large pulses, indicating significant calving events. The uppermost portion of Section IV at $<1.5 \mathrm{mbsf}$ is characterized by a small supply of only clay-sized sediment indicating predominantly pelagic sedimentation.

\section{Discussion}

\section{Early Pliocene}

Although there is general consensus that the Southern Ocean experienced higher temperatures between 5.0 and 3.7 Ma (e.g., Bohaty and Harwood, 1998), considerable debate exists about its effect on the dynamics of the East Antarctic ice sheet. Southern Ocean records have high concentrations of IRD between 5.3 and 3.4 Ma (e.g., Warnke et al., 1992), indicating substantial iceberg production from marine-based glaciers. Glacial unconformities and diamictites (Bart, 2001; Passchier et al., 2003) within lower Pliocene strata on the Antarctic continental shelf are consistent with ice-sheet expansions during this time. However, the record from Site 1165 indicates that the Lambert Glacier was most likely wetbased with a grounding line staying landward of the shelf break. Four major glacial advance and retreat cycles can be identified between $\sim 5.2$ and $\sim 3.5 \mathrm{Ma}$, based on interpretations of cyclic changes in sedimentological properties in the sediment drift.

\section{Middle Pliocene}

The large supply of predominantly clay-sized material with a large illite component to Site 1165 at $\sim 3.5 \mathrm{Ma}$ is consistent with extensive glacial erosion of marine sediments during glacial expansion to the shelf break. Between 3.5 and $3.1 \mathrm{Ma}$, sedimentation was cyclical with three interglacial periods, identified as smectite-rich structureless hemipelagic clays, between laminated glacial beds interpreted as meltwater plumites (cf. Pudsey, 2000). The mid-Pliocene (3.3-3.0 Ma) is characterized as a period of higher global sea surface temperatures (Dowsett et al., 1996). Warmer waters likely resulted in increased melting of marine termini during glacials, producing the meltwater plumites, and reduced sea ice conditions (Whitehead et al., 2005) during interglacials.

\section{Late Pliocene-early Pleistocene}

The sedimentary record from the shelf site (1166), shows cyclical changes in proglacial sedimentary facies 3.2-2.5 Ma indicating a grounding line oscillating landward of the inner shelf drillsite, followed by glacial expansion after 2.7-2.5 Ma (Passchier et al., 2003). At Site 1165, the 3-2.5 Ma interval is a condensed section with possible hiatus at the top. From $2.5 \mathrm{Ma}$ a gradual 
increase in the kaolinite content of the clay fraction (Junttila et al., 2005) signals excavation of an overdeepened glacial trough by an ice stream within an ice sheet that became largely frozen to its bed (Passchier et al., 2003; Rebesco et al., 2006).

\section{Bipolar effects from 11 Ma onward}

At $\sim 1 \mathrm{Ma}$, IRD at Site 1165 increased abruptly, coinciding with a 1.1-0.8 Ma increase in terrigenous supply at Site 745 (Joseph, et al., 2002). Ice-proximal sediment records indicate that $\mathrm{NH}$ glaciations intensified with large ice-sheets expanding onto the continental margins between 1.0 and 0.7 Ma (e.g., Andrews, 1993; Piper et al., 1994; Spielhagen et al., 1997; Sejrup et al., 2000). The major advance and retreat phases of NH icesheets produced significant sea level effects of $>100 \mathrm{~m}$, causing larger portions of the termini of Antarctic marinebased ice streams to become buoyant during interglacial phases. It is possible that the middle Pleistocene IRD layers at Site 1165 represent iceberg rafting events in response to $\mathrm{NH}$ deglaciation and associated sea level effects. Studies on cores with better chronological resolution for the late Pleistocene are necessary to test this hypothesis.

The upper part of Site 1165 lacks an IRD influence, consistent with decreased activity on the Prydz Fan after $0.78 \mathrm{Ma}$ (Passchier et al., 2003). Numerical modeling studies of erosion and sediment supply suggested that continued excavation and overdeepening of the glacial trough partially constricted ice advances of the Lambert Glacier in the Late Pleistocene (Taylor et al., 2004).

\section{Concluding remarks}

A high-resolution terrigenous particle size record of Site 1165 , interpreted in the context of a continental shelfslope-rise transect indicates major changes in the behavior of the East Antarctic ice sheet during the past 5.2 Myr. The Lambert Glacier was wet-based until $\sim 2.5 \mathrm{Ma}$ experiencing major advance and retreat phases as expressed in the cyclical changes of the sedimentary record on the continental rise. After $2.5 \mathrm{Ma}$ the ice stream stabilized until $\sim 1 \mathrm{Ma}$, when pulses of IRD delivered to Site 1165 suggest that NH glaciations may have affected the Lambert ice stream through sea level effects. This study demonstrates that further studies of the ice sheet history both in Antarctica and the Northern Hemisphere are needed to determine their role in forcings and feedbacks of $\delta{ }^{18} \mathrm{O}$ and eustatic records for the past $5 \mathrm{Myr}$.

Acknowledgments. D. Warnke and T. Naish are thanked for helpful reviews. The Ocean Drilling Program provided the samples.

\section{References}

Andrews, J.T. (1993), Changes in the silt and clay-size mineralogy of sediments at Ocean Drilling Program Site 645B, Baffin Bay, Can. J. Earth Sci., 30, 2448-2452.

Bart, P. (2001), Did the Antarctic ice sheets expand during the early Pliocene?, Geology, 29, 67-70.

Bohaty, S.M. and D.M. Harwood (1998), Southern Ocean Pliocene paleotemperature variation from high-resolution silicoflagellate biostratigraphy, Mar. Micropal., 33, 241-272.
Chappell, J. (2002), Sea level changes forced ice breakouts in the Last Glacial cycle: new results from coral terraces, Quat. Sci. Rev., 21, 10, 1229-1240.

Dowsett H., Barron, J., Poore, R. (1996), Middle Pliocene sea surface temperatures: a global reconstruction, Mar. Micropal., 27, 13-25.

Ehrmann, W., Grobe, H. (1991), Cyclic sedimentation at sites 745 and 746, in Proc. Ocean Drill. Program, Sci. Res, 119, edited by J. Barron and B. Larsen, pp. 225-237, doi:10.2973/odp.proc.sr.119.123.1991

Gradstein, F.M., Ogg, J.G., and A.G. Smith (2004), A Geologic Time Scale, Cambridge University Press, Cambridge.

Joseph, L.H., Rea, D.K., van der Pluijm, B.A., and J.D. Gleason (2002), Antarctic environmental variability since the late Miocene: ODP Site 745, the East Kerguelen sediment drift, Earth Planet. Sci. Lett., 201, 127-142.

Junttila, J., Ruikka, M., and Strand, K. (2005), Clay-mineral assemblages in high-resolution Plio-Pleistocene interval at ODP Site 1165, Prydz Bay, Antarctica, Global Planet. Change, 45, 151-163.

Lambeck, K., Esat, T. M. and E.-K. Potter (2002), Links between climate and sea levels for the past three million years, Nature, 419, 199-206.

Naish, T. (1997), Constraints on the amplitude of late Pliocene eustatic sea-level fluctuations : new evidence from the New Zealand shallowmarine sediment record, Geology, 25, 1139-1142.

Passchier, S., O’Brien, P.E., Damuth, J.E., Januszczak, N., Handwerger, D.A. and J.M. Whitehead (2003), Pliocene-Pleistocene glaciomarine sedimentation in eastern Prydz Bay and development of the Prydz trough-mouth fan, ODP Sites 1166 and 1167, East Antarctica, Mar. Geol., 199, 279-305.

Piper, D.J.W., Mudie, P.J., Aksu, A.E., and K.I. Skene (1994), A 1 Ma record of sediment flux south of the Grand Banks used to infer the development of glaciation in southeastern Canada, Quat. Sci. Rev., 13, 23-37.

Pudsey, C.J. (2000), Sedimentation on the continental rise west of the Antarctic Peninsula over the last three glacial cycles, Mar. Geol., 167, 313-338.

Sejrup, H.P., Larsen, E., Landvik, J., King, E.L., Haflidason, H., and A. Nesje (2000), Quaternary glaciations in southern Fennoscandia: evidence from southeastern Norway and the northern North Sea region, Quat. Sci. Rev., 19, 667-685.

Raymo, M.E., Lisiecki, L.E., and K.H. Nisancioglu (2006), PlioPleistocene ice volume, Antarctic climate, and the global $\delta{ }^{18} \mathrm{O}$ record, Science, 313, 492-495.

Rebesco, M., Camerlenghi, A., Geletti, R., and M. Canals (2006), Margin architecture reveals the transition to the modern Antarctic ice sheet ca. 3 Ma, Geology, 34, 301-304.

Shipboard Scientific Part (2001), Site 1165, in: Ocean Drilling Program Initial Reports Vol. 188, edited by P.E. O'Brien, A.K. Cooper and C. Richter, doi:10.2973/odp.proc.ir.188.103.2001

Spielhagen, R.F. and 14 others (1997), Arctic Ocean evidence for late Quaternary initiation of northern Eurasian ice sheets, Geology, 25, 783-786.

Taylor, J., Siegert, M.J., Payne, A.J., Hambrey, M.J., O’Brien, P.E., Cooper, A.K. and G. Leitchenkov (2004), Topographic controls on post-Oligocene changes in ice-sheet dynamics, Prydz Bay region, East Antarctica, Geology, 32, 197-200.

Warnke, D.A., Allen, C.P., Mueller, D.W., Hodell, D.A. and C. Brunner (1992), Miocene-Pliocene Antarctic glacial evolution: a synthesis of ice-rafted debris, stable isotope, and planktonic foraminiferal indicators, ODP Leg 114, in The Antarctic Paleoenvironment: A Perspective on Global Change Part One, edited by J.P. Kennett and D.A. Warnke, Antarctic Research Series, American Geophysical Union, Washington D.C., pp. 311-325.

Warnke, D.A., Richter, C., Florindo, F., Damuth, J.E., Balsam, W.L., Strand, K., Ruikka, M., Juntila, J., Theissen, K., and P. Quilty (2004), Data report: HiRISC (High-Resolution Integrated Stratigraphy Committee) Pliocene-Pleistocene interval, 0-50 mbsf, at ODP Leg 188 Site 1165, Prydz Bay, Antarctica, in Proc. ODP, Sci. Results, 188, edited by A.K. Cooper, P.E. O'Brien, and C. Richter http://wwwodp.tamu.edu/publications/188_SR/VOLUME/CHAPTERS/014.PDE.

Whitehead, J.M., Wotherspoon, S., and S.M. Bohaty (2005), Minimal Antarctic sea ice during the Pliocene. Geology, 33, 137-140. 